\title{
Concepts of Recognition of Seagoing Service and Certificates to Crew Members of Warships in Accordance with STCW Convention
}

\author{
Ivo Raffanellia, Jakša Miškovića, Ivica Pavićb
}

The paper analyzes the concepts of application of the International Convention on Standards of Training, Certification and Watchkeeping for Seafarers, 1978, with amendments 2010 (STCW Convention), in the segment of recognition of seagoing service and certification for crew members of warships. Although the STCW Convention does not apply directly to warships, the Parties have the right to continue to recognize seagoing service and certificates of the crew members of their warships. There are different concepts of solutions related to this issue. The paper particularly analyzes legal framework under the STCW Convention. Concepts are compared in several NATO member states through a review and analysis of legal solutions and available training programs from these countries. Similarities

\section{KEY WORDS \\ $\sim$ STCW Convention \\ $\sim$ Warships \\ $\sim$ Seagoing service \\ $\sim$ Certification}

and differences of the analyzed concepts are identified. Also, a general model of application in the national frameworks is developed. The authors conclude that it is possible to talk about the principle according to which seagoing service and certificates of the crew members of warships acquired during training and service on warships has been recognized with the fulfilment of the appropriate conditions prescribed by the Parties.

\section{INTRODUCTION}

The STCW Convention is the fundamental convention issued by the International Maritime Organization (IMO) to regulate, among other things, issues relating to training and certification of seafarers on conventional ships (Safety of Life at Sea ships, SOLAS ships). The STCW Convention also recognizes the possibility that each Party may continue to accept naval certificates and sea going service on warships. The purpose of this provision is to enable crew members of warships to exercise the right for recognition of appropriate naval certificates and seagoing service in order to have the possibility to continue the career on merchant ships. Navies educate their officers primarily at naval academies. The education programs are different according to their content and scope. The paper analyzes the education systems of naval officers in the United States of America, United Kingdom, Kingdom of Denmark and Federal Republic of Germany. The similarities and differences of these systems are identified. The paper also analyzes the status of seagoing service of the Croatian Navy officers and the recognition 
of their certification and training. Recognizing the need of crew members of warships, after completing their naval career, to be enabled to continue their career on merchant ships, the Parties have developed mechanisms for the recognition of seagoing service and naval certificates on the basis of the provisions of the STCW Convention. Since each country has its own education system for naval officers, the above mentioned mechanisms differ in each country. These mechanisms have been formalized through agreements between relevant military and civilian governmental authorities responsible for the implementation of the STCW Convention. The paper analyzes the concepts applied in the United Kingdom, United States of America, Kingdom of Denmark, and Federal Republic of Germany. Based on the analysis of the above mentioned training and education systems and concepts, a general model for the recognition of seagoing service and certificates for crew members of warships has been developed and proposed for application in national legislation of the Parties.

\section{LEGAL FRAMEWORK}

Since a warship is a non-conventional ship (non-SOLAS ship), national legal and to a certain extent international regulations apply to her. The warship is part of the armed forces of the sovereign state and its legal status is particularly determined in the international law (Rudolf, 2012). Legal status, sovereign immunity and exclusions of warships are governed by the United Nations Convention on the Law of the Sea (UNCLOS) (Pavić et al., 2018). This special legal status also applies to the crew members of warships. Taking into considerations the purpose of warships, navies develop their own education systems, training standards and certification of crew members. Accordingly, warships are exempt from the direct application of international legal regime under the STCW Convention. Under the provisions of Article III "The Convention shall apply to - seafarers serving on board seagoing ships entitled to fly the flag of a Party except to those serving on board,

a) Warships, naval auxiliaries or other ships owned or operated by a State and engaged only on governmental noncommercial service. However, each Party shall ensure, by the adoption of appropriate measures not impairing the operations or operational capabilities of such ships owned or operated by it, the persons serving on board such ships meet the requirements of the Convention so far as is reasonable and practicable,

b) fishing vessels,

c) pleasure yachts not engaged in trade, or

d) wooden ships of primitive build (STCW Convention, 2011)."

Thus, the provision of Article III a) allows that Parties shall independently take measures to regulate the application of the Convention on their own warships. This provision constitutes the basic rule enabling regulation of issues related to recognition of sea going service and certificates for crew members of warships. Due to the above mentioned specific legal status of warships, these issues are under the exclusive jurisdiction of flag states. This provision also takes into account that the application of the STCW Convention does not affect operations and operational capabilities of warships. ${ }^{1}$ This means that the crew members of warships are entitled to the recognition of a seagoing service and issuance of appropriate certificates, but that such certificates are not necessary for the performance of service on warships.

Furthermore, the STCW Convention in Article B-IX (Guidance regarding equivalents) defines: "Naval certificates may continue to be accepted and certificates of service may continue to be issued to naval officers as equivalents under Article IX, provided that the requirements of the Convention are met" (STCW Convention, 2011). This means that naval certificates had been recognized even before new regulations and amendments of STCW Convention entered into force; thus, the Parties are encouraged to continue to apply this practice.

In Article IX Equivalents, it is stated that: "The Convention shall not prevent an Administration from retaining or adopting other educational and training arrangements, including those involving seagoing service and shipboard organization especially adapted to technical developments and to special types of ships and trades, provided that the level of seagoing service, knowledge and efficiency as regards navigational and technical handling of ship and cargo ensures a degree of safety at sea and has a preventive effect as regards pollution at least equivalent to the requirements of the Convention. Details of such arrangements shall be reported as early as practicable to the Secretary General who shall circulate such particulars to all Parties (STCW Convention, 2011)." This provision enables the possibility of recognizing seagoing service and certificates acquired when exercising duties on different types of ships or different organizations. It is applied to service on warships and other governmental ships, piloting service, safety at sea related duties carried out in the appropriate state's authorities, and in educational institutions for seafarers.

\section{EDUCATION AND TRAINING SYSTEMS FOR NAVAL OFFICERS}

Education and training systems for naval officers differ from country to country. Those systems are composed of several levels required to perform duties throughout the entire military career. This paper analyzes only the basic level of education and

1. Other international conventions, such as UNCLOS, SOLAS and MARPOL Convention also contains similar provisions. These provisions are derived from the principle of sovereign immunity of warships. 
training, which enables the performance of duties on warships. Each country develops its own system tailored to its own needs. Basically, we can talk about two types of education and training systems for naval officers. The first system involves education at naval academies, and consists of a combination of academic education, basic military training and to some extent specialist training. Such a system has been developed in a number of states (BOEl, 2018). ${ }^{2}$ The paper particularly analyzed the education system for the US Navy. In the United States naval officers are educated at the United States Naval Academy. The education lasts for four years and consists of several fields such as engineering and weapons, mathematics and science, humanities and social sciences, professional development, leadership, ethics and law (United States Naval Academy Course Catalog, 2018). After graduation, a foundational training is organized with the aim to prepare young officers to perform their first duties on board of the US Navy surface ships. In order to perform these duties, the officers are trained in Surface Warfare Officers School through Basic Division Officer Course. The Course is an eight-week course of instruction ${ }^{3}$ designed to provide the fundamental training for new Division Officers to succeed when they first step aboard ship. The course offers instruction in division-level administration, engineering, leadership, damage control, practical instruction in navigation, seamanship and ship handling (Surface Warfare Officers School Command, 2018). The second system foresees the academic education at universities, while basic and specialist trainings are conducted in appropriate naval training centers. In principle, we can talk about two approaches to this system, one developed in the United Kingdom (and Kingdom of Denmark) and the other in the Federal Republic of Germany. In the UK, after completing education, officers' training is carried out at Britannia Royal Naval College (BRNC). This training is composed of pre-initial naval training, basic and professional training. Preinitial naval training is a 15 -week course aimed to provide basic skills deemed necessary to commence Initial Naval Training (PREINTO, 2018). Basic training, named Initial Naval Training (Officer), is a 30-week course with the aim to prepare young officers for subsequent phases of the specialist training (INTO, 2018). The Course is split into two phases (militarization and marinization) (Royal Navy: What's the training like, 2018). The above mentioned courses include (among other) seamanship, navigation, boat driving and boat handling topics. The last phase is professional training which is conducted as a combination of time at sea and time in the classroom (Royal Navy: What's the training like, 2018).

2. This system has been developed in the United States, Italy, France, Greece, Spain, Romania, etc. (BOEI, 2018).

3. There is a lot of criticism for the training of surface warfare officers (SWO) in the US Navy. Some of them are related to computer-based approach to this Course, while other criticisms are related to insufficient level of standardization of training for SWO. See more on this issue at (McGuffie, 2009).
In the Kingdom of Denmark, after completing education, officers' training is carried out at the Royal Danish Defense College. The Officer Education contains branch-specific basic officers' training programs. The Officer Education contains three elements basic military training, academic military modules and service specific courses (vocational training). The Naval Officer Education has three service specific programs: Operations, Engineering, Weapons and Electronics (Royal Danish Defence College, Officer Education, 2018). In the Federal Republic of Germany, basic naval education is carried out at the Naval Academy in Mürwik (Marineschule Mürwik), after which cadets go to study at the University of Bundeswehr in order to acquire academic education. After graduation, students become cadets again and return to the Naval Academy and other naval schools for advanced training (specialization) (Naval Academy Mürwik, 2018). Within naval education, part of the training is carried out on board German Navy sailing ship Gorch Fock, while within the framework of advanced training (depending on specialization) seamanship and officer-of-the-watch training is conducted (Naval Academy Mürwik, 2018). From the analyzed examples it is obvious that education and training of naval officers differ from education and training of merchant navy officers. For this reason, similarities and differences are identified at appropriate governmental level. Officers (and in most cases other crew members of warships) are able to obtain certificates by complying with appropriate conditions based on previously recognized seagoing service on warships.

\section{ANALYSIS OF CONCEPTS FOR THE RECOGNITION OF SEAGOING SERVICE AND CERTIFICATES ON WARSHIPS IN THE UNITED KINGDOM, UNITED STATES OF AMERICA, KINGDOM OF DENMARK AND FEDERAL REPUBLIC OF GERMANY}

Seagoing service and naval certificates are neither recognized nor approved by the relevant authorities of all the Parties. Therefore, the concepts of four different NATO countries will be analyzed. Relevant examples from the United Kingdom, United States of America, Kingdom of Denmark, and Federal Republic of Germany are taken into consideration. These four states, distinguished NATO members and parties to the conventions related to international maritime transport, fully recognize seagoing service and naval certificates. Since education, training and service on their warships differ from merchant ships, these countries have reached appropriate agreements with their respective authorities and acknowledged all the specificities and differences in terms of service on warships and merchant ships. The agreements have defined the ways and conditions for recognizing certificates and seagoing services to crew members of warships and their alignment with the STCW Convention. 


\section{The United Kingdom concept}

In the United Kingdom, on 7December, 1999a Memorandum of Understanding between the Royal Navy (RN) and the Maritime and Coastguard Agency (MCA) was signed (Memorandum of Understanding between Royal Navy and the Maritime and Coastguard Agency) (Royal Navy Officers: Merchant Navy Master's Certificate, 2018). Pursuant to the Agreement, the manner of recognizing seagoing service and certificates of naval officers to obtain STCW certificates of competency has been developed. Discussions with the MCA have commenced to develop a similar Memorandum of Understanding for engineer officers and ratings. More widely, the RN continues to seek to align its training with the STCW requirements. The RN Resettlement Service also offers impartial advice on second careers with many strong links with maritime sector organizations and companies (the UK Parlament, Shipping: Written Question - 39966, 2016). The RN and MCA have recognized differences in training between the $\mathrm{RN}$ and merchant navy. With this agreement, seagoing service and certificates on warships for the RN officers are recognized. The agreement defines "accelerated route" of equating duties acquired in the RN with similar duties in the merchant navy defined in the STCW Convention. Figure 1 (Royal Navy to Merchant Navy Transfer Flow Diagram, 2018) presents two different ways of advancement and promotion for naval officers in merchant navy, recognizing the differences between commanding officer of warship and other naval officers. Seagoing service for the RN officers is recognized by the MCA, and they are provided accelerated route to the acquisition of award of MCA officer-of-the-watch (OOW) STCW II/1 certificate. When the RN officers acquire this certificate, they have the possibility to continue their careers according to the usual way of advancement for merchant navy officers. The RN commanding officers' seagoing service is particularly recognized by the MCA, and they are provided accelerated route to acquisition of the award of MCA master STCWII/2 certificate (Royal Navy to Merchant Navy Transfer Flow Diagram, 2018). Officers (including commanding officers) are requested to pass familiarization with merchant ships before gaining their OOW certificate in the merchant navy (Royal Navy to Merchant Navy Transfer Flow Diagram, 2018). The RN officers graduate from BRNC. BRNC program is different from the training programs for merchant navy officers. Therefore, it is compulsory for the RN officers to attend courses that they did not attend during the naval career. Typically, the areas in which the RN officers are required to undergo training, beyond that required for the $\mathrm{RN}$ service, are cargo work, stability, medical care and shipmaster's business and law. There is no provision for an RN officer to be granted a master's certificate without first holding an STCW OOW certificate followed by a chief mate's certificate. However, an accelerated route has been agreed, recognizing high quality of the RN training and experience (Royal Navy Officers: Merchant Navy Master's Certificate, 2018). The accelerated route means that commanding officers of the RN warships have the possibility to acquire chief mate certificate after six months of seagoing service as OOW and master's certificate after six months of seagoing service as chief mate or twelve months as OOW. The agreement also solved the procedure for recognizing seagoing service to the crew members of the engine department, and the process of recognition of seagoing service for other crew members of warships is also in progress.

\section{The United States concept}

In the United States, a detailed mechanism for recognizing seagoing service and certificates for all ranks and duties on warships has been developed. The mechanism has been elaborated in detail in Blueprint to Mariner publication. The US Coast Guard (USCG), in accordance with its competences, coordinates the process of recognizing navy qualifications and duties of crew members, while the National Maritime Center, as part of this organization, evaluates seagoing service and acquired qualifications during the US Navy service and issue the appropriate certificates (Blueprint to Mariner, 2017). As a general rule, for all duties on US Navy ships, appropriate equivalents have been developed in various segments of civilian affairs, not only and not necessary in merchant navy. In this way, all crew members of US Navy ships were enabled to achieving another career after completing their service in the US Navy. The USCG equates all titles of US Navy crew members that can be linked to positions in merchant navy according to the principles of the rank and duties. To acquire these titles, it is prescribed for each duty to have appropriate period of time spent on service on board of US Navy ships and training required under the STCW Convention (Table 1) (Blueprint to Mariner, 2017). Appointments in service of the engine department are recognized in accordance with similar principles as in the deck department from a crew member forming part of a watch in engine room to the officer in charge of an engineering watch in engine room (Table 2) (Blueprint to Mariner, 2017). USCG license eligibility must be assessed, caseby-case, based on the individual's unique training, experience, duty assignments, and in-service opportunities (Blueprint to Mariner, 2017). 


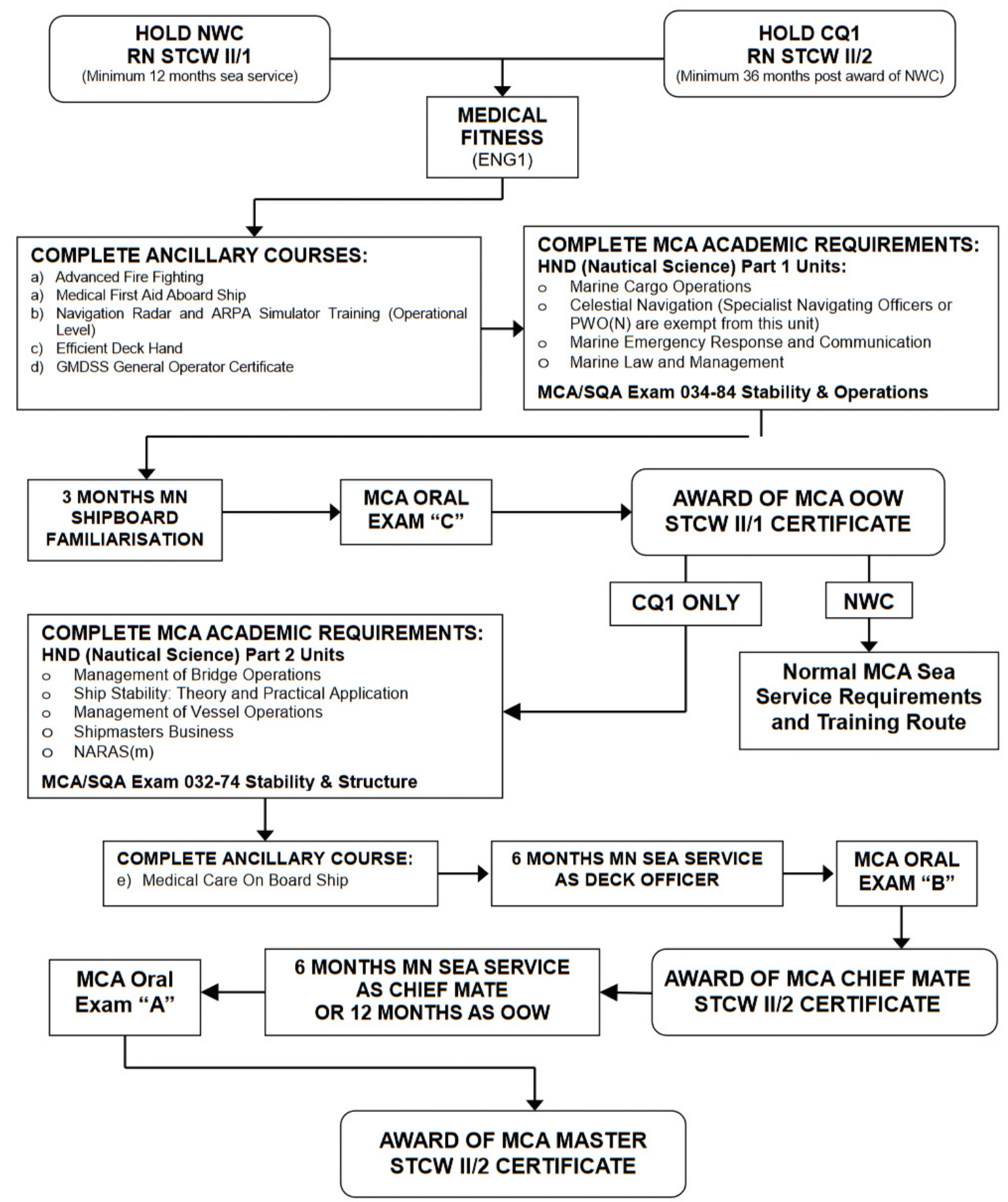

Figure 1.

Royal Navy to Merchant Navy transfer flow diagram (Royal Navy to Merchant Navy Transfer Flow Diagram, 2018). 
Table 1.

Minimum Sea Time for Deck Endorsements (Blueprint to Mariner, 2017).

\section{US Navy Rank}

E1-E3
Military rating

SA, SN, BM, QM, GM

\section{Merchant marine equivalent}

Ordinary Seaman, Wiper, Steward (Food Handler)

\section{Sea time required}

None

None
STCW \& other training

Support Level Basic

Training - BT

Ratings Forming Part of a Navigational Watch RFPNW

\begin{tabular}{lll}
\hline E4-E6 & BM & Able Seaman \\
\hline E4-E6 & Deck Ratings & AB OSV \\
\hline E4-E6 & Deck Ratings & AB MODU
\end{tabular}

\begin{tabular}{lll}
\hline E4-E6 & Deck Ratings & AB Special \\
\hline E4-E6 & Deck Ratings & AB Limited
\end{tabular}

E4-E6, E7-E9 \& 01-06, Any USNA Grad wit DWO Letter

\author{
AB Unlimited
} QMOW, DWO, Ops, XO $\mathrm{CO}$

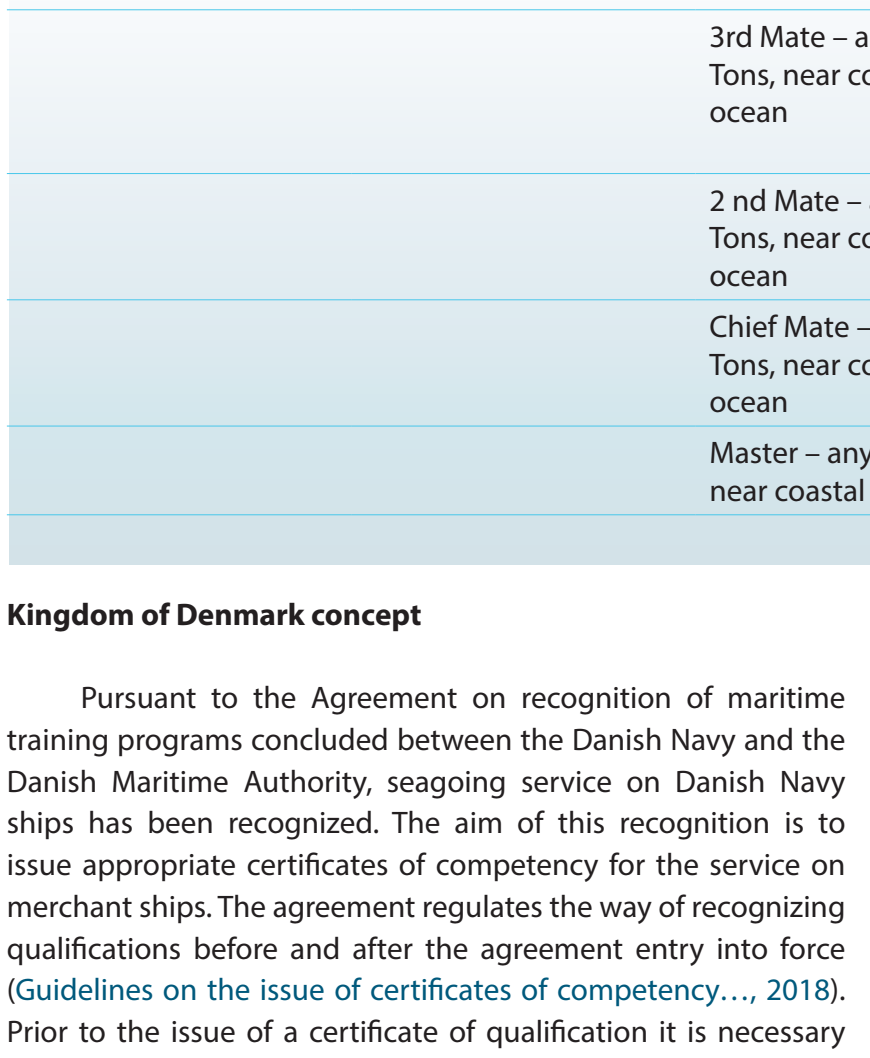

$\begin{array}{ll}1080 \text { days } & \text { BT, Lifeboatman, RFPNW } \\ \begin{array}{l}180 \text { days on navigable } \\ \text { waters of US }\end{array} & \text { BT, Lifeboatman, RFPNW } \\ \begin{array}{l}360 \text { days on Vessel over } \\ \text { 65 Feet on navigable } \\ \text { waters of US }\end{array} & \text { BT, Lifeboatman, RFPNW } \\ \end{array}$

360 days on navigable BT, Lifeboatman, RFPNW waters of US

540 days on vessel over BT, Lifeboatman, RFPNW 100 GRT on navigable waters of US

1080 days of Deck
Service with 180 days as
a Bridge Watchstander and Lifeboatman

1080 days of deck service with 180 days as a Bridge Watchstander and Lifeboatman

360 days as 3rd Mate

720 days as a 2 nd Mate

BT, Lifeboatman, RFPNW Management Level NVIC 10-14 - CM/Master
BT, Lifeboatman, RFPNW

BT, Lifeboatman, RFPNW Operational Level NVIC 12-14-OICNW 
On the basis of documentation provided, the qualifications are equalized for officers, non-commissioned officers, and sailors in service of the deck and engine departments on Bundesmarine ships and crafts. BSH will issue certificates of competency for the third and second officers in charge of a navigational watch on ships of 500 GT or more, officers in charge of a navigational watch on ships up to 500 GT in coastal navigation, officers in charge of an engineering watch in the engine room with a propulsion power of $750 \mathrm{~kW}$ or more, officers in charge of an engineering watch in the engine room with a propulsion power up to 750 $\mathrm{kW}$ and certificates of ratings forming part of a navigational watch and of watch in the engine room (Vereinbarung zwischen dem Bundesamt..., 2018). The prerequisites for acquiring OOW certificate are to perform:

a minimum seagoing service of thirty six months on Bundesmarine ships for officers,

a minimum seagoing service of sixty months on Bundesmarine ships for non-commissioned officers,

first degree Bundesmarine certificate, and

three months of familiarization on a merchant ship with a training record book signed by the master of the ship or by a superior officer (Vereinbarung zwischen dem Bundesamt..., 2018).

Former members of Bundesmarine with an OOW certificate and third-degree Bundesmarine certificate may, after nine months of navigation, exercise the right to gain a certificate of chief mate on a ship of 3,000 GT or more. Officers who have completed second-degree Bundesmarine certificate may, after six months of navigation, exercise the right to obtain the certificate of chief mate on a ship of 3,000 GT or more (Vereinbarung zwischen dem Bundesamt..., 2018). Bundesmarine certificates, training and seagoing services carried out in the engine department on Bundesmarine ships and crafts shall be recognized by $\mathrm{BSH}$. The prerequisites for acquiring certificates for officers in charge of an engineering watch in the engine room with a propulsion power of $750 \mathrm{~kW}$ or more and certificates for officers in charge of an engineering watch in the engine room with a propulsion power up to $750 \mathrm{~kW}$ are to perform:

a minimum of seagoing service from twelve to sixty months on Bundesmarine ships depending on the rank and level of education, and

three months of familiarization on a merchant ship with a training record book signed by the master of the ship or by a superior officer (Vereinbarung zwischen dem Bundesamt..., 2018).

Officers and non-commissioned officers from engine department have been granted recognition of the qualification up to the level of the second engineer (Vereinbarung zwischen dem Bundesamt..., 2018). Sailors in service of the deck and engine departments have ability to acquire certificates of ratings forming part of the navigational watch or forming part of the watch in the engine room if they:

spent at least six months in service on Bundesmarine ships,

have adequate civilian training, and

if their service on Bundesmarine ships can be linked to activities on the deck or in the engine department (Vereinbarung zwischen dem Bundesamt..., 2018).

Crewmembers have no ability to achieve certificates of competency for the master on ships of 3,000 GT or more, and certificates of competency for the management level in the engine department on the basis of seagoing service from the Bundesmarine.

\section{OVERVIEW OF CROATIAN NAVY CONCEPT OF EDUCATION, TRAINING, RECOGNITION OF SEAGOING SERVICE AND CERTIFICATES ON WARSHIPS}

The concept of education and training for the Croatian Navy officers has changed a few times since its foundation. The concept was fundamentally based on the admission of officer candidates after graduation from the Faculty of Maritime Studies at the undergraduate or graduate level. After selection, candidates completed the basic officers' course. On completion of this course they were posted on their first duties on Croatian Navy ships. Apart from this concept, the concept of education and training of cadets was applied. After selection, the cadets were sent to the Faculty of Maritime Studies in Split for completing their bachelor academic studies. During studying they were provided with the basic military and naval training at camps. After having completed academic education, the cadets attended ten-month basic officer's course before their first assignment to the Croatian Navy ships. This concept was replaced by the development of a new program for cadets' academic education and training developed in cooperation between the Croatian Military Academy "Dr. Franjo Tuđman" and the University of Split. This program will fully standardize the education of future Croatian Navy officers. Analyzing relevant Croatian regulations, it was determined that Regulations for Seafarers' Certification and Certificates do not envisage obtaining the authorization of crew members who have accomplished seagoing service and certain appointments on the Croatian Navy ships (Regulations for Seafarers'..., 2013). The Regulation in Articles 11, 12, and 43 recognizes the seafarers serving on public ships certain rights in the national navigation (Regulations for Seafarers'..., 2013). The Regulations for Boats and Yachts (Article 86.c and 87.c) allow members of the Croatian Navy to acquire a Certificate of Training for the Category B or C boatmaster on the basis of evidence of completion of the basic non-commissioned officer's course or basic officer's course (Regulations for Boats and Yachts, 2005). Crew members of the Croatian Navy ships after completion of service on naval ships 
do not foresee the possibility of recognition of seagoing service, nor the duties they have carried out during their service on naval ships. Current Croatian regulations do not allow recognition of seagoing service or qualifications for crewmembers of the Croatian Navy ships. Therefore, it is proposed to appropriately harmonize the Croatian regulations with the provisions of the STCW Convention in accordance with the examples analyzed in this paper.

\section{GENERAL MODEL OF APPLICATION IN NATIONAL FRAMEWORKS}

According to the analyses of the education and training systems, agreements between navies and appropriate maritime authorities of particular states, similarities and differences related to recognition of seagoing service and certificates for naval officers in the deck department have been identified and are presented in Table 3.

Table 3.

Requirements for the recognition of seagoing service and certificates for naval officers in deck department.

\begin{tabular}{|c|c|c|c|c|c|c|c|}
\hline State & $\begin{array}{l}\text { Education } \\
\text { system }\end{array}$ & $\begin{array}{l}\text { Training } \\
\text { system }\end{array}$ & $\begin{array}{l}\text { Minimum } \\
\text { seagoing } \\
\text { service on } \\
\text { naval ships }\end{array}$ & $\begin{array}{l}\text { Minimum MN } \\
\text { shipboard } \\
\text { filiarization }\end{array}$ & $\begin{array}{l}\text { Exam } \\
\text { equirements }\end{array}$ & $\begin{array}{l}\text { OOW } \\
\text { certificate }\end{array}$ & $\begin{array}{l}\text { CO naval } \\
\text { certificate } \\
\text { recognition }\end{array}$ \\
\hline USA & $\begin{array}{l}\text { United } \\
\text { States Naval } \\
\text { Academy }\end{array}$ & $\begin{array}{l}\text { Basic Division } \\
\text { officer course }\end{array}$ & $\begin{array}{l}1080 \text { days of } \\
\text { deck service }\end{array}$ & N/A & Yes & $\begin{array}{l}\text { OOW STCW } \\
\text { II/1 }\end{array}$ & N/A \\
\hline UK & $\begin{array}{l}\text { Academic } \\
\text { education at } \\
\text { University }\end{array}$ & $\begin{array}{l}\text { Pre-initial } \\
\text { naval training, } \\
\text { initial naval } \\
\text { training }\end{array}$ & 12 months & 3 months & $\begin{array}{l}\text { Yes } \\
\text { (oral exam) }\end{array}$ & $\begin{array}{l}\text { OOW STCW } \\
\text { II/1 }\end{array}$ & Yes \\
\hline Denmark & $\begin{array}{l}\text { Academic } \\
\text { education at } \\
\text { University }\end{array}$ & $\begin{array}{l}\text { Basic military } \\
\text { training, } \\
\text { academic } \\
\text { military } \\
\text { modules and } \\
\text { vocational } \\
\text { training }\end{array}$ & 12 months & $\begin{array}{l}3 \text { months as a } \\
\text { pernumerary } \\
\text { mate }\end{array}$ & Yes & $\begin{array}{l}\text { OOW STCW } \\
\text { II/1 }\end{array}$ & $\mathrm{N} / \mathrm{A}$ \\
\hline Germany & $\begin{array}{l}\text { University of } \\
\text { Bundeswehr }\end{array}$ & $\begin{array}{l}\text { Basic naval } \\
\text { education, } \\
\text { advanced } \\
\text { training } \\
\text { specialization }\end{array}$ & 36 months & 3 months & Yes & $\begin{array}{l}\text { OOW STCW } \\
\text { II/1 }\end{array}$ & Yes \\
\hline Croatia & $\begin{array}{l}\text { Faculty of } \\
\text { Maritime } \\
\text { Studies }\end{array}$ & $\begin{array}{l}\text { Basic officer } \\
\text { course }\end{array}$ & N/A & N/A & $\mathrm{N} / \mathrm{A}$ & N/A & $\mathrm{N} / \mathrm{A}$ \\
\hline
\end{tabular}

Although the analysis of the examples in the selected countries has shown that the problem of recognition of seagoing service and the certificates of crew members of warships is solely the responsibility of the flag state, a general model applicable to all the STCW Parties can be proposed. The general requirements are: existence of academic education, naval training with the elements of the STCW Convention requirements, seagoing service on warships, familiarization on merchant navy ships and appropriate exams. Specific requirements are the alignment of education and training with the requirements of the STCW Convention before obtaining the appropriate STCW certificates. 


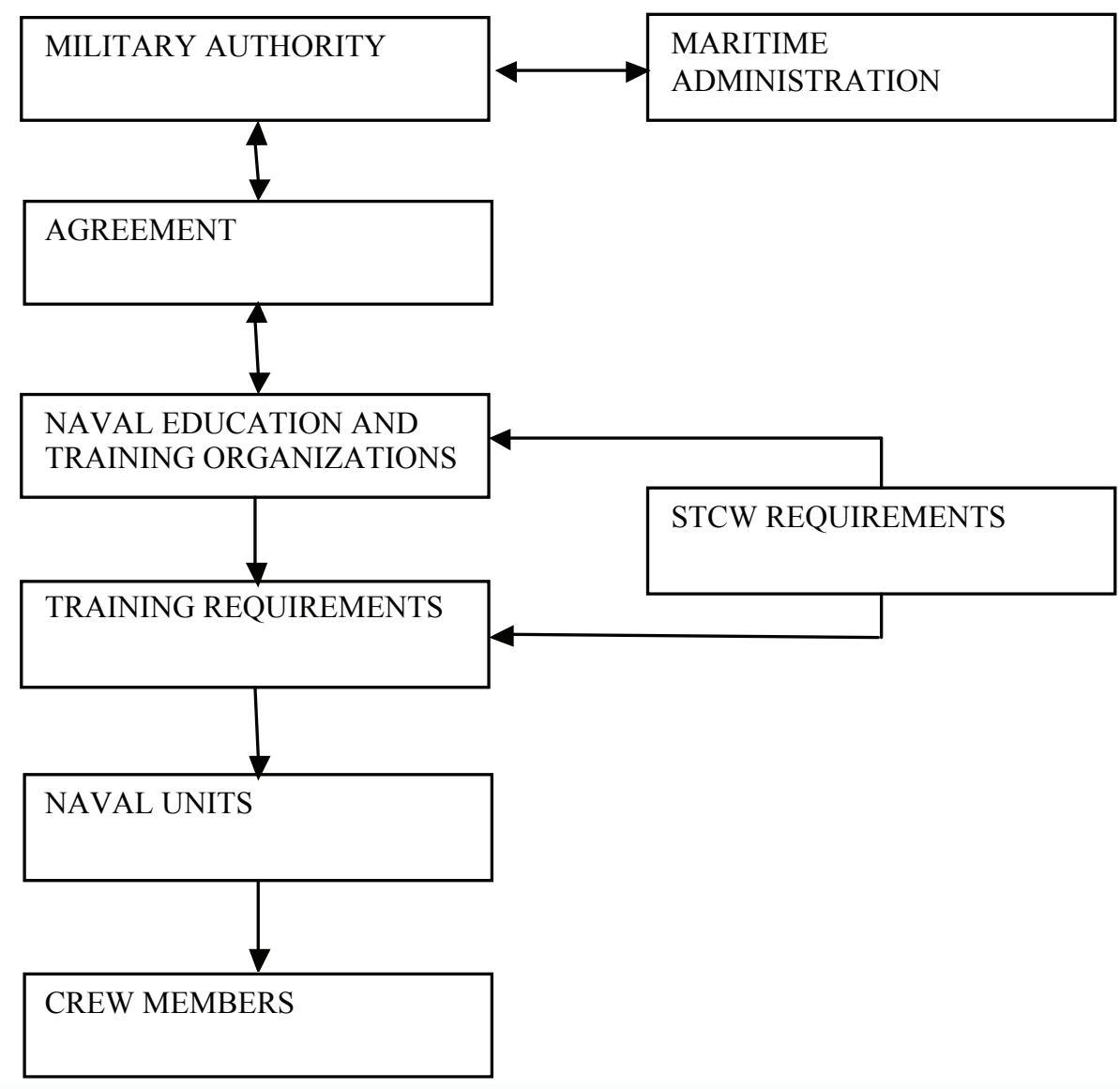

Figure 2.

General model for the recognition of seagoing service and certificates for crew members of warships.

According to the proposed model at the flag state level, it is necessary to sign an appropriate agreement between the military authority and the maritime administration. At this level, the similarities and differences between education and training requirements of the STCW Convention and the naval programs should be identified. The agreement must also define the full methodology and clear criteria for the recognition of seagoing service and certificates for crew members of warships. In order to reduce future differences, the agreement must include mechanisms for monitoring of the implementation and evaluation of education and training requirements of the STCW Convention, without affecting the operational capabilities of warships.

Naval education and training organizations' responsibility is to continuously align naval education and training programs with the STCW Convention to the extent applicable to warships. Training requirements should encompass specific training requirements for naval units and crew members as well as the training requirements from the STCW convention.
According to the proposed model, military authority is responsible to issue certificates of accomplishment of navigation service and naval certificates for all the crew members of warships. The Maritime Authority is responsible to determine differences between the STCW Convention requirements and naval certificates. In accordance with these differences the type and content of the exams for crew members of warships will be developed.

\section{CONCLUSION}

Naval power of an individual country is not only measured in the number of gray warships but also in the size of its merchant navy. With the end of military career officers, non-commissioned officers, and sailors who served on naval ships should be able to re-qualify with the recognition of adequate qualification and seagoing services achieved on naval ships in order to be able to continue their career on merchant ships. In this way, they will continue to contribute to the naval power of the country. 
In the analyzed examples, the states have applied the provision of Article III of the STCW Convention and have drawn up appropriate rules governing the recognition of qualifications and seagoing services achieved on naval ships. It is noticeable that there is no single mechanism for recognizing these qualifications, and each one of analyzed systems and concepts has its specifics incorporated in national regulations. Officers from all of these navies are admitted to the navy service and enable the acquisition of officer's certificates in the merchant navy. Seagoing service of commanding officers from some of aforementioned navies in that sense have a special status and they are enabled to acquire a higher qualifications in the merchant navy as compared to other naval officers. Officers (including commanding officers) of naval ships, before gaining their first certificate at the merchant navy, have obligation to pass through the familiarization process on merchant ships. Each country recognizes differences in the training of naval officers in relation to merchant navy officers and enables naval officers to achieve prescribed training in a shortened program. All countries take into account the experience, high quality of education and training of naval officers, and enable them to accelerate promotions on merchant navy ships through the above mentioned processes. National regulations take into account all the specificities of education and training, qualifications and duties acquired by crew members of naval ships both in the deck and the engine departments. All the specific situations which are not foreseen in the national regulations are considered separately on a case-by-case basis and are resolved positively by taking into account all the acquired qualifications during service on naval ships. Based on a general model for recognition of seagoing service and certificates for crew members of warships, it is proposed to implement the provisions of Article III of STCW Convention into national regulations and to provide legal prerequisites for recognition of qualifications and seagoing service of crew members of warships. According to the model, it is proposed to draw up the appropriate agreement between relevant government bodies. Pursuant to the agreement, a corresponding regulation should be drawn up, which should take into consideration and regulate all the specificities of recognition of seagoing service and qualifications taking into account relevant naval certificates. This would allow a uniform application of the STCW Convention to a maximum possible extent.

\section{REFERENCES}

Blueprint to Mariner, U.S. Coast Guard Licensure Process - and - Available Funding Processes, Document Version - 1.5, U.S. Navy's Credentials Program Office/Navy COOL, the U.S. Coast Guard's MK Rating Force Master Chief, and the U.S. Army Transportation School Maritime \& Intermodal Training Department, 2017. Available at: https://www.cool.navy.mil/usn/otr/otr-blueprint.htm

Britannia Royal Naval College, Initial Naval Training (Officer) (INT(O)). Available at https://www.royalnavy.mod.uk/-/media/royal-navyresponsive/documents/idt/ brnc/03_01-into-jan_17.pdf?la=en-gb
European initiative for the exchange of young military officers, Basic Officer Education Institutions (BOEI) in the European Union (Defence Universities, Military, Naval, Air Force Academies and Schools). Available at http://www.emilyo.eu/ node/48

Guidelines on the issue of certificates of competency and certificates of proficiency, etc, Danish Maritime Authority. Available at: https://www.dma.dk / SoefarendeBemanding/Documents/Vejledning\%20om\%20udstedelse\%20af\%20 soenaeringsbeviser\%20inkl\%20Louises\%20rettelser.pdf

IMO: International Convention on Standards of Training, Certification and Watchkeeping for Seafarers, STCW including 2010 Manilla amendmends, Third consolidated edition, 2011. Croydon: CPI Group (UK).

McGuffie, M., 2009. A Rude Awakening. US Naval Institute Proceedings Magazine 135(1) pp. 1,271. Available at https://www.usni.org /magazines/ proceedings/2009-01/rude-awakening

Naval Academy Mürwik. Available at https://www.revolvy.com/main/index.php?s $=\mathrm{Naval}+$ Academy+M\%C3\%BCrwik

Pavić, I., Mišković, J., Sanchez-Varela, Z., 2018. Application of the MARPOL convention on warships. Proceedings of 18th International Conference on Transport Science ICTS 2018. Ljubljana.

Pre-Initial Naval Training (Officer) - (PRE-INT(O)). Available at: https://www. royalnavy.mod.uk/-/media/royal-navy-responsive/documents/idt/brnc/03_05-pre_ into-jan_17.pdf?la=en-gb

Regulations for Boats and Yachts, 2005. Official Gazette of the Republic of Croatia 2005(27).

Regulations for Seafarers' Certifications and Certificates, 2013. Official Gazette of the Republic of Croatia 2013(130).

Royal Danish Defence College, Officer education. Available at http://www.fak.dk/ en/education/Pages/Officer Programme.aspx

Royal Navy Officers: Merchant Navy Master's Certificate. Available at https://www. theyworkforyou.com/wrans/?id=2001-04-10a.172.4

Royal Navy to Merchant Navy Transfer Flow Diagram. Available at https://www. warsashacademy.co.uk/careers/resources/royal-navy-to-merchant-navy-transferflow-diagram.pdf

Royal Navy: What's the training like? Available at: https://www.royalnavy.mod.uk/ careers/joining/get-ready-to-join/royal-navy-officer/what-the-training-like

Rudolf, D., 2012. Enciklopedijski rječnik međunarodnoga prava mora. Zagreb: Matica Hrvatska.

Surface Warfare Officers School Command. Available at: https://www.cnic.navy. $\mathrm{mil} /$ regions/cnrma/installations/ns_newport/about/tenant_commands/surface_ warfare_officers_school_command.html

The UK Parlament, Shipping: Written question - 39966. Available at https:// www.parliament.uk/written-questions-answers-statements/written-question/ commons/2016-06-08/39966

United States Naval Academy Course Catalog. Available at https://www.usna.edu/ Academics/Majors-and-Courses/Course-Catalog.php

Vereinbarung zwischen dem Bundesamt für Seeschifffahrt und Hydrographie und der Deutschen Marine (Marineamt) über die Anerkennung von Befähigungen, die bei der Deutschen Marine erworben wurden, als Voraussetzungen für den Erwerb von Befähigungszeugnissen und Seefunkzeugnissen für den Dienst auf Kauffahrteischiffen. Available at https://www.deutsche-flagge.de/de/redaktion/ dokumente/dokumente-bsh/vereinbarung 